\title{
ドリフトピン接合部を用いたニ EXPERIMENTAL STUDY ON THE TWO 層木質ラーメン構造の実験的研 STORY TIMBER FRAME STRUCTURE 究 USING DRIFT PIN JOINTS
}

\author{
荘所直哉 一 $* 1$ 大野義昭 $-* 2$ \\ 藤谷義信 $-* 3$ 大橋好光 $-* 4$ \\ キーワード : \\ 実大実験, 木質ラーメン構造, 構造用 LVL, ドリフトピン, モーメント抵抗接 \\ 合部 \\ Keywords : \\ Full-scale experiment, Timber frame structure, Structural LVL, Drift pin, \\ Moment-resisting joint
}

\section{Naoya SHOJO $* 1$ \\ Yoshiaki OHNO - $* 2$ \\ Yoshinobu FUJITANI $-* 3$ \\ Yoshimitsu OHASH $-* 4$}

In this paper, the static loading experiment on the two story timber frame structure using drift pins are reported. The experiment was carried out in two construction stages. The first stage is the one in which the columns, the beams and the floors were constructed, and the second stage is the one in which the bearing walls were added to them. The contribution to the stiffness of this wooden structure by the frame and the bearing walls are examined experimentally.

\section{1.はじめに}

木質住宅構造のストック価値を向上させるには，構造材の耐久性 向上,住み手が間取りを変更しやすい構造空間の確立が必要であり, 建替ることなく利用できる住宅の工法開発が要求されている。木質 ラーメン構造は, 住まい手のライフサイクルに適応しやすく, リフ オームにおいても動かし難い耐力壁から開放される躯体システムで あり，住宅のストック価值向上のために有効であると考えられる。

筆者らがこれまで報告した木質ラーメン構造の接合部に関する 研究では，丸龬とドリフトピンを用いた接合部を提案し，実験や数 值シミュレーションを通してモーメント抵抗接合部の性能を評価し

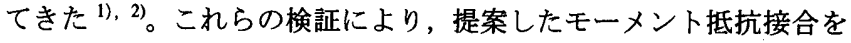
用いた木質ラーメン構造の建設が可能となり，2 層 2. 方向の木質 ーメン構造物を建設した。本報は，これを試験体として行った静的 加力実験の架構の荷重-変位関係についてのみ述べる。実験は 2 段階 の建設過程で行った。第 1 段階は柱, 梁等で構成したラーメン架構 および床構面の施工が終了した時点（以後，骨組段階）で，第 2 段 階は第 1 段階の躯体に在来軸組工法の耐力壁を追加設置した時点 （以後，壁付段階）である。

\section{2. 試験体概要}

\section{1 構造概要}

構造方法は, ラーメン構造に一部在来軸組工法で使用される耐力 壁を併用させた。柱, 梁等の主要構造部には構造用 LVL を使用し, 耐力壁は厚さ $9 \mathrm{~mm}$ の構造用合板，床構面は厚さ $28 \mathrm{~mm}$ の構造用合 板を使用した。主要構成材料の一覧を表 1 に示す。

試験体の構造伏図, 骨組図を図 1に示す。ラーメン架構は Y O-X0Y1-X1 通りで囲まれた区画と Y0-X2-Y1-X3 通りで囲まれた区画の

\begin{tabular}{|c|c|c|c|}
\hline & $\begin{array}{l}\text { 樹種 } \\
\text { 材種 }\end{array}$ & $\begin{array}{c}\text { 規格 } \\
\text { 機械等級区分 }\end{array}$ & $\begin{array}{l}\text { 断面 (mm) } \\
\text { 幅 } \times \text { せい }\end{array}$ \\
\hline 柱（大） & $\begin{array}{c}\text { ラジアータパイン } \\
\text { 桡造用 LVL }\end{array}$ & $\begin{array}{c}\mathrm{JAS} \text { 規格 } \\
\text { 曲げヤング係数区分 } 110 \mathrm{E}\end{array}$ & $360 \times 360$ \\
\hline 柱（小） & $\begin{array}{c}\text { ラジアータパイン } \\
\text { 構造用 LVL }\end{array}$ & $\begin{array}{c}\mathrm{JAS} \text { 規格 } \\
\text { 曲げャング係数区分 } 80 \mathrm{E}\end{array}$ & $105 \times 105$ \\
\hline 大梁 & $\begin{array}{c}\text { ラジアータパイン } \\
\text { 構造用 LVL }\end{array}$ & $\begin{array}{c}\text { JAS 規格 } \\
\text { 曲げヤング係数区分 } 110 \mathrm{E}\end{array}$ & $150 \times 480$ \\
\hline 小梁 & $\begin{array}{c}\text { ラジアータパイン } \\
\text { 構造用 LVL }\end{array}$ & $\begin{array}{c}\mathrm{JAS} \text { 規格 } \\
\text { 曲げヤング係数区分 } 110 \mathrm{E}\end{array}$ & $105 \times 240$ \\
\hline
\end{tabular}
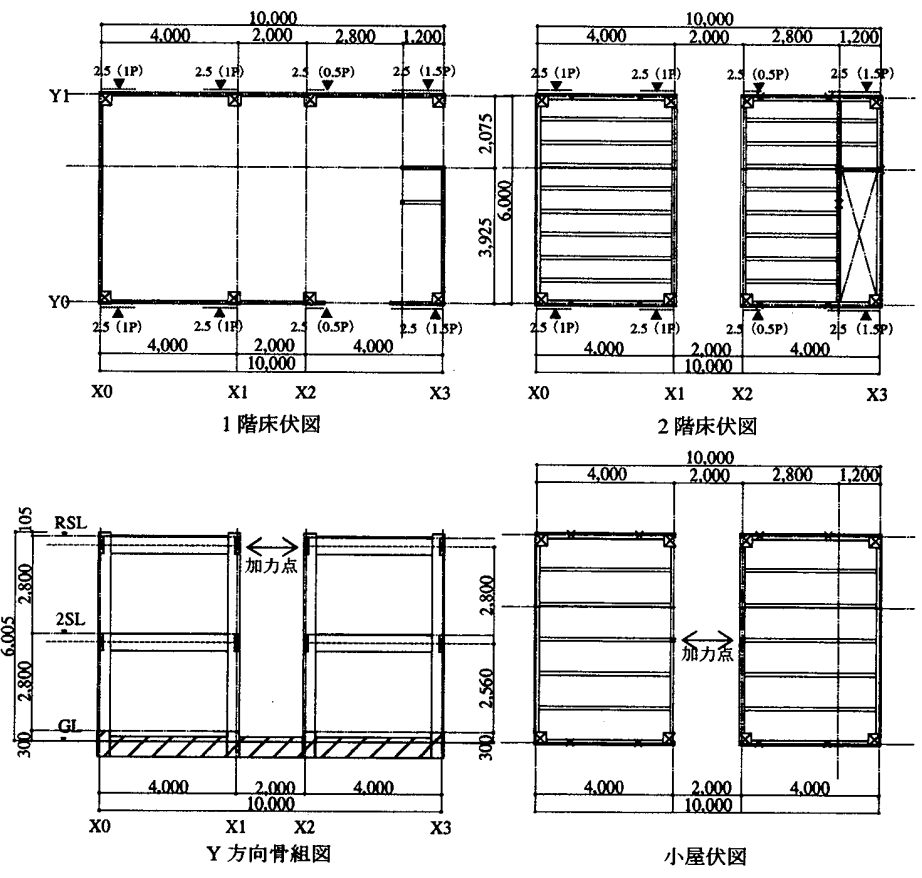

図 1 試験体の構造伏図および骨組図

\footnotetext{
*1 明石工業高等専門学校建築学科 助手 - 博士 (工学)

(广674-8501 兵庫県明石市魚住町西岡679-3)

*2 㤦ウッドワン住宅構法開発室 室長・博士(工学)

*3 広島国際大学社会環境科学部 教授. 工博

*4 武蔵工業大学工学部 教授・工博
} 
辺に配置してあり，区画の辺には大梁を設けている。Y0-X0-Y1-X1 と Y0-X2-Y1-X3 通りで囲まれたラーメン架構の区画には $2 \mathrm{~m}$ の間隔 を設けているが, これは静的加力実験でこの間にジャッキを眯ませ， お互いのラーメン架構の区画を反力壁として加力するためである。 壁付段階の実験では，1，2 階の外周部に在来軸組工法の耐力壁を設 けた。図中のム印は耐力壁位置を示し, カッコ外の数值は壁倍率, カッコ内の数值は壁長さを示す。また, P はモジュールを示し $1 \mathrm{P}=1 \mathrm{~m}$

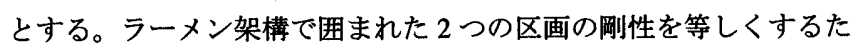
め，2つのラーメン架構で囲まれた区画の壁量は等しくした。

試験体の写真を図 2に示す。
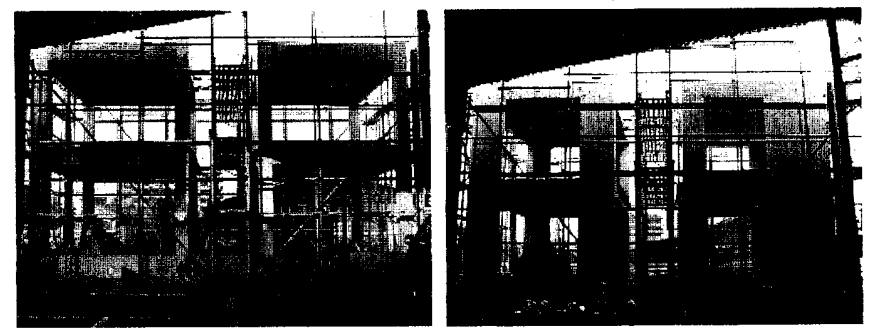

図 2 試験体の様子（左；骨組段階，右 ; 壁付段階）

\section{2 柱-梁接合部および柱脚接合部の仕様}

柱 - 梁接合部の接合方法は，丸鋼を柱と梁に挿入し，丸鋼にドリ フトピンを打ち込み固定する。ドリフトピンの打ち込み間隔は柱側 を $60 \mathrm{~mm}$, 梁側を $120 \mathrm{~mm}$ とし, 1 本の丸鎆につき柱側 5 本, 梁側 5 本の計 10 本，接合部全体では 20 本のドリフトピンを使用する。2 方向ラーメン構造なので, 柱 - 梁接合部では $\mathrm{X}$ 方向と $\mathrm{Y}$ 方向の丸鋼 がぶつかる。そのためにY 方向の丸銅を $60 \mathrm{~mm}$ 下げた。

柱脚接合部の接合方法は，基礎にアンカーした丸鋼に柱を挿入し， 丸鎆にドリフトピンを打ち込み固定する。ドリフトピンの打ち込み 間隔は $120 \mathrm{~mm}$ とし, ドリフトピンの本数は 1 本の丸鋼につき 5 本 とし，接合部全体では 20 本のドリフトピンを使用する。接合部の詳 細を図 3に，施工時の様子を図 4に示す。
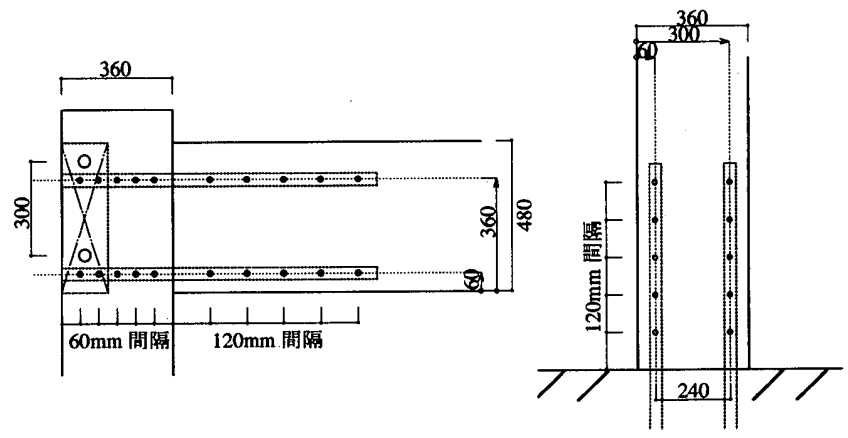

図 3 接合部詳細図（左 : 柱梁部, 右 : 柱脚部)

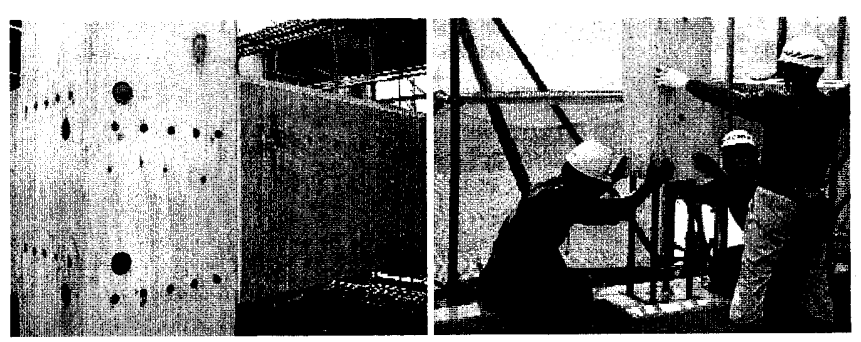

図 4 施工時の様子（左 : 柱梁部，右 : 柱脚部)

\section{3 小梁接合部および床組の仕様}

ラーメン架構で囲まれた区画の内部は小梁を配直して床組を形 成した。小梁の接合部はモーメントに抵抗しない。接合方法は，3 本のボルトで大梁に緊結した 2 つ折りの鋼板を小梁に挿入し，2 本 の鋼管ピンによって固定する（図 5 参照）。

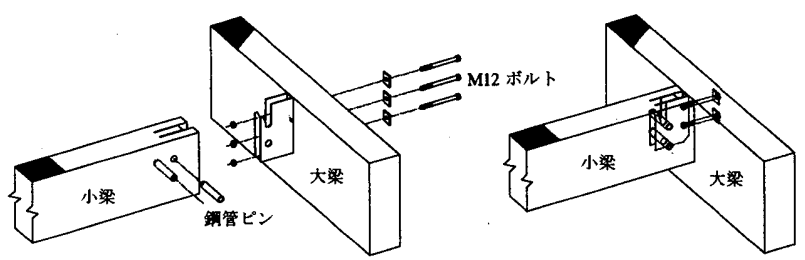

図 5 小梁接合部の仕様

床組は火打ち梁と根太を省略し，28mm の構造用合板を直接床組 に釘止めした面材張り床構面である。面材の短边方向は N75を用い て間隔 $150 \mathrm{~mm}$ で横架材に川の字となるよう釘打ちし, 面材の長辺 方向は $\phi 9$ のドリフトピンで面材の長手方向相互の接合をした。

\section{3. 静的加力実験}

\section{1 実験方法}

実験は柱, 梁等で構成したラーメン架構および床構面の施工が終 了した骨組段階と骨組段階の躯体に在来軸組工法の耐力壁を追加設 置した壁付段階の 2 段階で行った。各段階ともに同様の実験を行っ た。試験体各部の変位とひずみについて測定した。試験体に設置し た変位計の設置位置を図 6に, ひずみグージの設置位置を図 7に示 す。ひずみゲージは Y0-X0-Y1-X1 通りで囲まれたユニットのみ測定 をした。

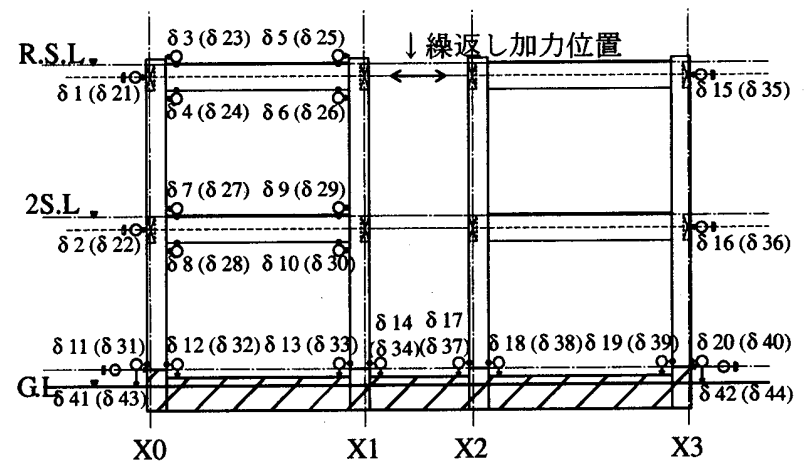

図 6 変位計の設置位置（括弧内は $\mathrm{Y} 1$ 通りの番号）

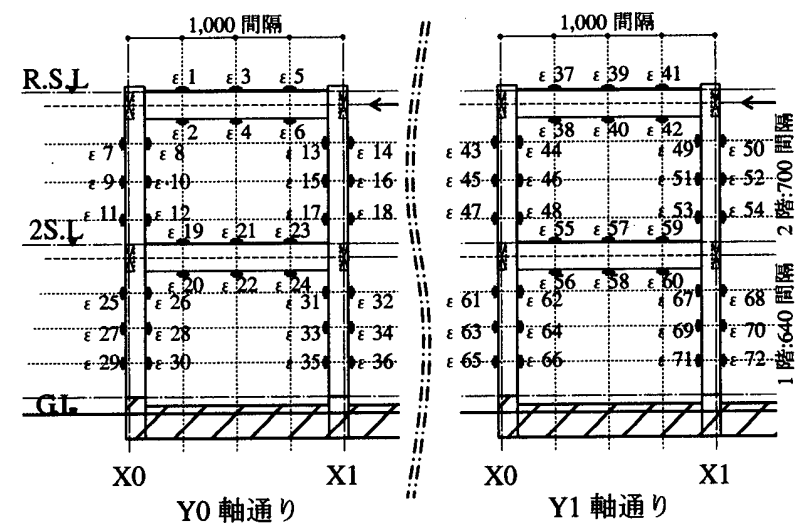

図 7 ひずみゲージの設置位置 


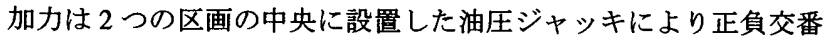
繰返しで行う。ジャッキの設置高さは小屋レベルとし，2 つの区画 のうち，主な測定対象は Y0-X0-Y1-X1 通りで囲まれる区画で, この とき Y0-X2-Y1-X3 通りで囲まれる区画は反力壁の役割を果たす。以 下の表 2 に繰返しサイクル数と試験体の変形角および小屋レベルの 変位の関係について示す。

表 2 繰返しサイクルと試験体の変形の関係

\begin{tabular}{|l|c|c|c|c|c|c|}
\hline サイクル数 & 1 & 2 & 3 & 4 & 5 & 6 \\
\hline 変形角 $(\mathrm{rad})$ & $\pm 1 / 450$ & $\pm 1 / 300$ & $\pm 1 / 225$ & $\pm 1 / 150$ & $\pm 1 / 100$ & $\pm 1 / 75$ \\
\hline 変位 $(\mathrm{mm})$ & \pm 11.9 & \pm 17.9 & \pm 23.8 & \pm 35.7 & \pm 53.6 & \pm 71.5 \\
\hline
\end{tabular}

\section{2 実験結果}

実験は, 骨組段階で $120 \mathrm{kN}$, 壁付段階で $150 \mathrm{kN}$ 程度の最大荷重を 加えた。これは当初 $\mathrm{C}_{0}=0.2$ で設計した水平力の 5 倍以上の荷重を加 えたことになる。しかし，ラーメン架構の骨組には全く損傷は見ら れなかった。壁付段階では，1/100 rad を超えた辺りから合板耐力壁 の破壊音が響き，釘の滑りも目立つようになったが，骨組には損傷 は見られなかった。

Y0-X0-Y1-X1 通りで囲まれる区画において, 骨組段階, 壁付段階 でロードセルより測定された荷重値と 1,2 層の層間変位の関係につ いて以下の図 3, 図 4 に示す。

1,2 層の層間変位は次式により算出した。

- 1 層の層間変位 ${ }_{1} \delta$

- 2 層の層間変位 ${ }_{2} \delta$

$$
{ }_{1} \delta=\left(\delta_{2}+\delta_{22}\right) / 2-\left(\delta_{41}+\delta_{43}\right) / 2
$$

$$
{ }_{2} \delta=\left(\delta_{1}+\delta_{21}\right) / 2-\left(\delta_{2}+\delta_{22}\right) / 2
$$

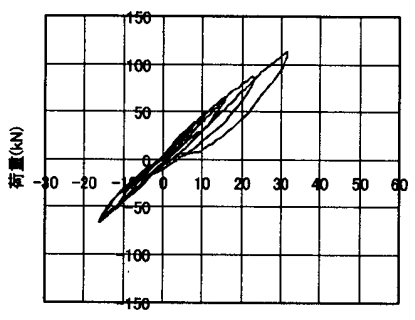

鲋费位 $(\mathrm{mm})$

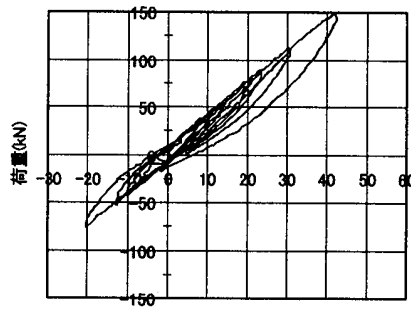

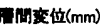

図 81 層の層間変位（左：骨組段階，右 : 壁付段階）
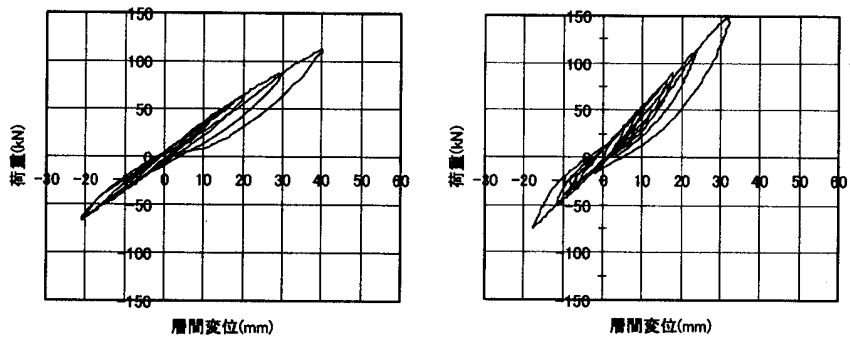

図 92 層の層間変位（左 : 骨組段階，右 : 壁付段階）

\section{4. 静的加力実験の検証}

\section{1 検証方法}

検証は，3 次元の試験体を $\mathrm{Y} 0, \mathrm{Y} 1$ 通りの 2 次元のフレームに置 き換えて行う。2 次元のフレームに置き換えて考えるとき，各通り
のフレームが負担する荷重が問題となるが，ここでは次の 2 通りの 方法によって Y0, Y1 通りのフレームが負担する荷重を決定する。 Case1）ロードセルで測定された荷重值を用いる方法

剛床仮定が成立し，試験体がねじれない場合，荷重は Y0，Y1 通 りに均等に分配されると考える。よって，Y0, Y1 通りが負担する 荷重はロードセルで測定された $1 / 2$ の荷重となる。

Case2）ひずみゲージから層せん断力を算出する方法

各層を 4 分割するように柱に配置したひずみゲージの測定值にヤ ング係数を乗じて曲げモーメント求め, せん断力を算出する（図 10 参照)。ここでヤング係数はヤング係数区分の $110 \mathrm{E}$ を用いた。

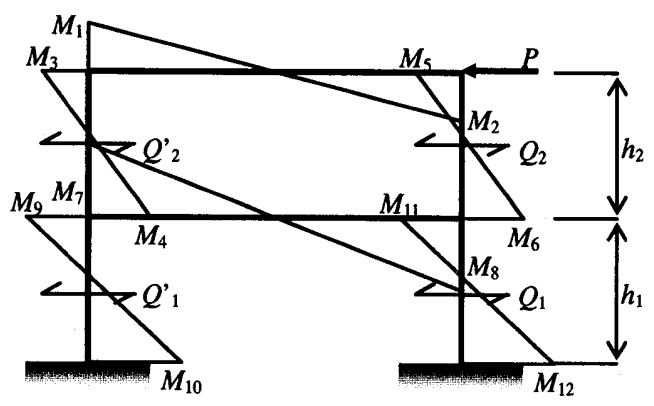

図 10 フレームの曲げモーメントとせん断力

図 10より, 各通りのフレームが負担する荷重 $P$ は次式により算 出する。本来, 荷重 $P$ は $Q_{1}+Q_{1}{ }^{\prime}$ もしくは $Q_{2}+Q_{2}$ 'であるが, ここで は各層の平均值の和とした。

$$
\begin{aligned}
Q_{1}= & \left(M_{11}+M_{12}\right) / h_{1}, \quad Q_{1}^{\prime}=\left(M_{9}+M_{10}\right) / h_{1} \\
Q_{2}= & \left(M_{5}+M_{6}\right) / h_{2}, \quad Q_{2}^{\prime}=\left(M_{3}+M_{4}\right) / h_{2} \\
& P=\left(Q_{1}+Q_{1}^{\prime}\right) / 2+\left(Q_{2}+Q_{2}^{\prime}\right) / 2
\end{aligned}
$$

また, 各層, 各通りの変位は次式により算出する。

・ 1 層の層間変位 ${ }_{1} \delta$

- 2 層の層間変位 ${ }_{2} \delta$

$$
{ }_{1} \delta_{Y 0}=\delta_{2}-\delta_{41},{ }_{1} \delta_{Y 1}=\delta_{22}-\delta_{43}
$$

$$
{ }_{2} \delta_{Y 0}=\delta_{1}-\delta_{2},{ }_{2} \delta_{Y 1}=\delta_{21}-\delta_{22}
$$

\section{2 フレームの荷重-層間変位関係}

Y0，Y1 通りのフレームが負担する荷重と各層の層間変位の関係 について調べる。Case1，Case2のそれぞれの仮定により算出した荷 重と層間変位の関係を図 11〜図 12 と, 図 13〜図 14に示す。
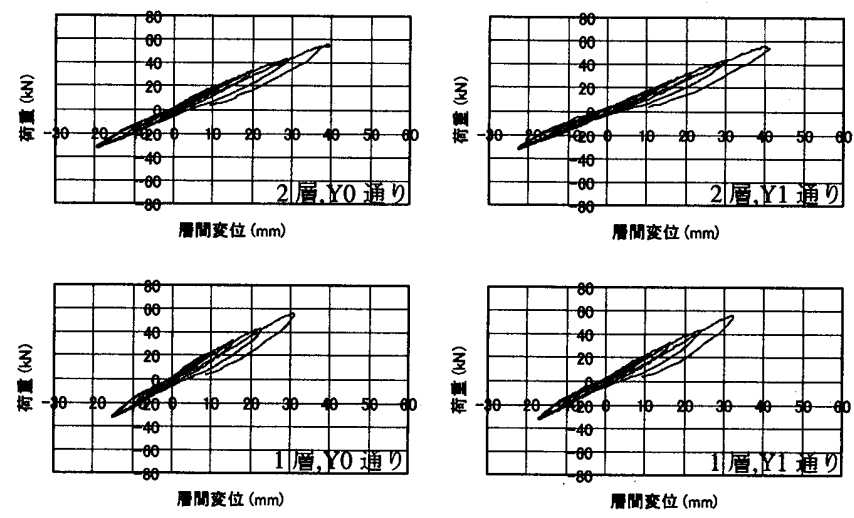

図 11 Case1（骨組段階）の荷重-層間変位関係 

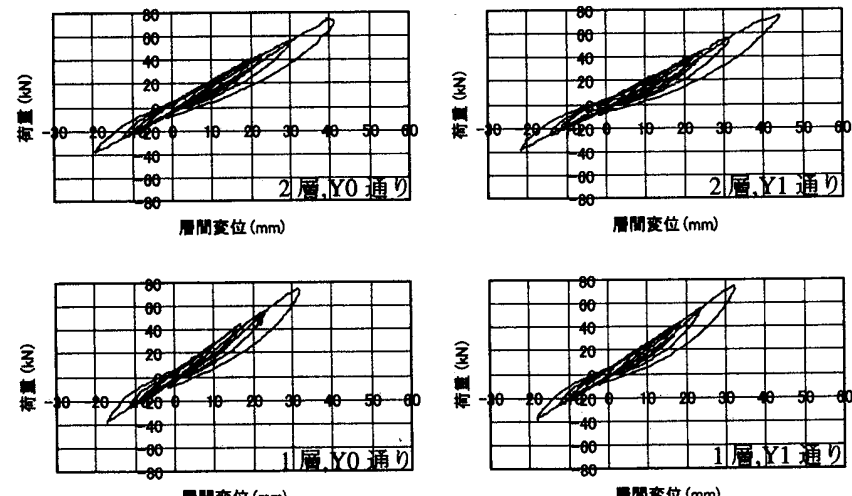

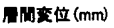

図 12 Case1（壁付段階）の荷重-層間変位関係
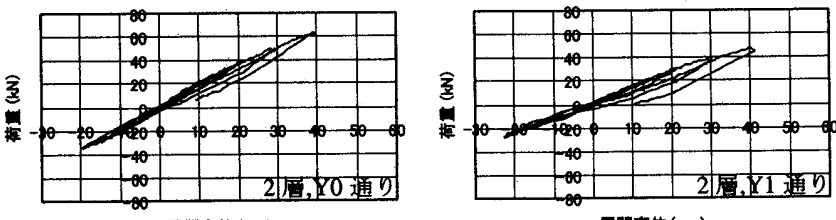

Ir用索位 $(\mathrm{mm})$
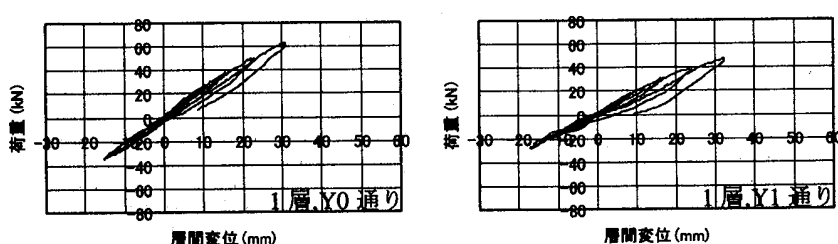

図 13 Case2 (骨組段階) の荷重-層間変位関係
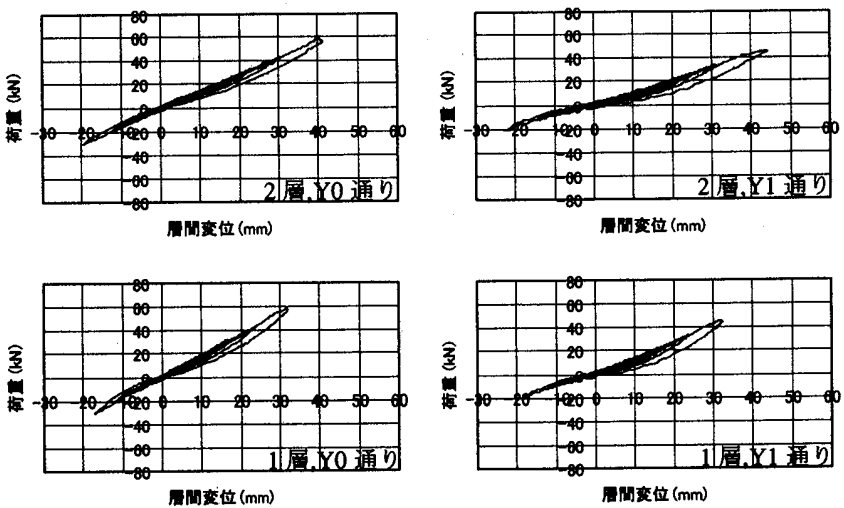

図 14 Case2（壁付段階）の荷重-層間変位関係

\section{3 考察}

Case2において，両段階共に Y1 通りより Y0 通りの方が若千荷重 の負担が大きくなっている。これは加力を $\mathrm{Y} 0$ 通りと $\mathrm{Y} 1$ 通りの中央 一ヶ所で行っているため, 試験体がねじれて各通りに等分に荷重が 流れていないためであると考えられる。また，各通りの変位值から もねじれていることがわかる。

骨組段階の Case1 と Case2 では荷重-層間変位関係は比較的一致し ているが，壁付段階では Case1 の荷重が大きくなった。Case2 は柱 のひずみ值から荷重を算出しているので，耐力壁の荷重負担を考㦄 することができないためであると考えられる。

ここで, 耐力壁が負担する荷重を次式から算出した。試験体がね じれたことによって生じる各通りの耐力壁の負担割合が不明である
ため, 各通りで均等に割り振った。

$$
P_{W}=\left\{P_{L}-\left(P_{Y 0}+P_{Y 1}\right)\right\} / 2
$$

\section{ここに,}

$P_{\mathrm{W}} \quad: \mathrm{Y} 0$ 通り, Y1 通りの耐力壁の負担荷重

$P_{L} \quad$ : ロードセルにより測定された荷重

$P_{Y 0}, P_{Y 1} \quad:$ 各通りのフレームが負担した荷重

骨組段階と壁付段階における骨組, 耐力壁の層剛性について比較 した (表 3参照)。層剛性は, 1/150 rad 時の変形角に相当する各層の 変位と荷重の関係から算出した。また, 構面としての性能評価とし て,同様に 1/150 rad 変形時の荷重を表 4に示す(共に Case2 で評価)。

表 3 層剛性の比較（単位: $\mathrm{kN} / \mathrm{m}$ )

\begin{tabular}{|c|c|c|c|c|c|}
\hline \multirow{2}{*}{ 層 } & \multirow{2}{*}{ 通り } & \multirow{2}{*}{ 骨組段階 } & \multicolumn{3}{|c|}{ 壁付段階 } \\
\cline { 4 - 6 } & & & 骨組 & 耐力壁 & 全体 \\
\hline \multirow{2}{*}{1} & $\mathrm{Y} 0$ & 2310 & 1810 & 840 & 2650 \\
\cline { 2 - 6 } & $\mathrm{Y} 1$ & 1790 & 1390 & 850 & 2240 \\
\hline \multirow{2}{*}{2} & $\mathrm{Y} 0$ & 1840 & 1420 & 820 & 2240 \\
\cline { 2 - 6 } & $\mathrm{Y} 1$ & 1420 & 1010 & 680 & 1690 \\
\hline
\end{tabular}

表 4 性能評価一覧（単位 : $\mathrm{kN}$ )

\begin{tabular}{|c|c|c|c|c|}
\hline \multirow{2}{*}{ 通り } & \multirow{2}{*}{ 骨組段階 } & \multicolumn{3}{|c|}{ 壁付段階 } \\
\cline { 3 - 5 } & & 骨組 & 耐力壁 & 全体 \\
\hline Y0 & 39.4 & 32.3 & 14.9 & 47.2 \\
\hline Y1 & 31.4 & 23.8 & 15.1 & 38.9 \\
\hline
\end{tabular}

骨組段階で一度加力したため, 壁付段階の骨組では層剛性が約 $400 \mathrm{kN} / \mathrm{m}$ 低くなっていることが分かる。また，骨組と耐力壁の剛性 比はおよそ $1: 2$ で骨組の惘性が高いことが分かった。耐力壁が負担 している耐力が約 $15.0 \mathrm{kN}$ で壁倍率換算すると約 3.5 倍となる。設置 した耐力壁の壁倍率は 2.5 倍なので，ばらつきや安全率などを考慮 すると期待通りの耐力を発揮したと考えられる。

\section{5. まとめ}

ドリフトピンを用いた二層木質ラーメン構造の静的加力実験を 行った。以下にまとめを示す。

・設計に用いた水平力の 5 倍を超える水平力に対しても骨組には 全く損傷は見られず，耐震性は高いと考えられる。

・骨組と耐力壁の剛性比を比較すると $2: 1$ で骨組の剛性が高いこ とが分かった。

\section{謝辞}

本研究に対し御協力を頂きました岩井哲先生（広島工業大学）, 松本慎也先生 (広島大学), 広島大学, 熊本県立大, 広島工業大学の 学生をはじめとする多くの関倸者に深く感謝致します。

\section{【参考文献】}

1）大野義昭, 槙島裕二, 荘所直哉, 乃込寞之, 藤谷義信, 大橋好光: ドリ フトピンを用いた木質ラーメン構造の柱 - 梁接合部に関する研究, 日本 建築学会構造系論文集, 第 567 号, pp.85-92, 2003.5

2）荘所直哉, 藤谷義信, 植岛裕二, 乃込寛之, 大野義昭, 大橋好光 : ドリ フトピンを用いた木質ラーメン構造の柱一梁接合部に関する研究 その 2 モーメント抵抗要素の実験と実大実験での検封、日本建築学会構造系 論文集，第 578 号，pp.91-97，2004.4

3）荘所直哉, 槙島裕二, 大野義昭, 藤谷義信, 大橋好光 : 木質ラーメン構 造の接合部に関する研究 その 14,15 , 日本建築学会大会学術請演梗概 集（東海）pp.29-32，2003.9

4）荘所直哉, 藤谷義信, 槙島裕二, 大野義昭, 大椅好光 : 常時微動測定に よる木質ラーメン構造の振動特性に関する研究, 構造工学論文集, Vol.49B, pp.579-584, 2003.3 [2005年 4 月 19 日原稿受理 2005 年 7 月22日採用決定 